\title{
JEDNAKOST U POSTUPOVNOM PRISTUPU PREMA SVAKOM MALOLJETNIKU U KAZNENOM POSTUPKU RADI OSIGURANJA PRAVIČNOG SUĐENJA I JEDNAKOSTI SVIH PRED ZAKONOM
}

Maja Vučić Blažić, univ. spec. crim.* Prof. dr. sc. Ljiljana Mikšaj-Todorović** Dijana Rizvić, mag. iur.***

\author{
UDK 343.138: 342.722- 053.2 \\ https://doi.org/10.30925/zpfsr.42.3.3 \\ Ur.: 22. ožujka 2021. \\ Pr.: 18. travnja 2021. \\ Izvorni znanstveni rad
}

\begin{abstract}
Sažetak
Svrha je ovoga rada, na temelju rezultata provedenog istraživanja, procijeniti primjenu jednakosti u postupovnom pristupu prema svakom maloljetniku radi osiguravanja pravičnog suđenja i jednakosti svih pred zakonom is tim $u$ vezi ponuditi konkretne izmjene zakonskih $i$ donošenje podzakonskih propisa. Analiziran je sadržaj izvješća centara za socijalnu skrb $(N=59)$ koja se sastavljaju za potrebe suda pri izricanja odgojnih mjera. Rezultati su pokazali da se izvješća znatno razlikuju te da je, u svakoj od 10 zakonski definiranih kategorija, u prosjeku prisutno između $12 \%$ i $63 \%$ očekivanih podataka odabranih diskrecijskom odlukom izvjestitelja. Time se argumentira zaključak o narušavanju primjene jednakosti u postupovnom pristupu prema svakom maloljetniku u etapi procjene. U radu su navedeni prijedlozi izmjena $i$ dopuna zakonskih i izrade podzakonskih propisa u svrhu poboljšanja primjene jednakosti u postupovnom pristupu.
\end{abstract}

Ključne riječi: maloljetni počinitelji; kriteriji; odgojne mjere; izvješća; sud za maloljetnike.

* Maja Vučić Blažić, univ. spec. crim., viša stručna savjetnica za tretman, Zatvorska bolnica u Zagrebu; vucicblazicmaja@gmail.com. ORCID: https://orcid.org/0000-0001-5289-4681.

** Dr. sc. Ljiljana Mikšaj-Todorović, redovita profesorica u trajnom zvanju, Edukacijskorehabilitacijski fakultet Sveučilišta u Zagrebu, Odsjek za kriminologiju; ljiljana.miksajtodorovic@erf.hr. ORCID: https://orcid.org/0000-0003-2347-6696.

*** Dijana Rizvić, mag. iur., sutkinja, Općinski kazneni sud u Zagrebu, Odjel za mladež; dijanarizvić@gmail.com. ORCID: https://orcid.org/0000-0001-5659-2038. 


\section{1. $U$ VOD}

Međunarodni propisi koji se odnose na zaštitu prava djece ${ }^{1}$ neizravno ili izravno zadiru u područje postupanja kada su djeca osumnjičenici ili optuženici u kaznenim postupcima. Temeljna su načela najbolji interes djeteta, pravo na zaštitu $i$ priliku za skladan razvoj, a težište je na dobrobiti maloljetnika i osiguranju da svaka reakcija prema njemu bude uvijek razmjerna okolnostima kako počinitelja, tako $i$ počinjenog kaznenog djela. ${ }^{2}$ Stoga se, u mnogim zemljama, a posebno potpisnicama međunarodnih propisa, svrhe izricanja sankcija maloljetnim počiniteljima definiraju na temelju socijalnog modela. ${ }^{3}$

U Republici Hrvatskoj, zakonom ${ }^{4}$ su propisani kriteriji ${ }^{5}$ za izricanje odgojnih mjera. Pri odlučivanju o odgojnoj mjeri sud će se, primarno ili pretežno rukovoditi socijalnim modelom sukladno s opisom svrhe maloljetničkih sankcija, ${ }^{6}$ gdje ključne riječi nikako ne asociraju na retribuciju, a to su: zaštita, briga, pomoć, nadzor, izobrazba, odgoj, razvoj ličnosti i jačanje osobne odgovornosti. Na sudu je, dakle, konačna procjena, hoće li pojedini počinitelj sve to najbolje dobiti ili postići ostankom u zajednici te djelomičnom ili potpunom institucionalizacijom. Kontekstualno, sud vodi računa i o općoj svrsi propisivanja, izricanja i primjene kazneno pravnih sankcija. ${ }^{7}$

Da bi dobio cjelovitu sliku o konkretnom maloljetnom počinitelju, sud treba

1 Vidi Ante Carić i Ivan Kustura, „Kamo ide hrvatsko maloljetničko kazneno zakonodavstvo?“, Zbornik radova Pravnog fakulteta u Splitu 47, br. 3 (2010): 605-620; Smjernice Odbora ministara Vijeća Europe o pravosuđu prilagođenom djeci, Odbor ministara VE, Program VE Izgradnja Europe za djecu i s djecom (2010); Neven Ricijaš, Dobre prakse i izazovi u kontekstu maloljetničke delinkvencije u Hrvatskoj, u: ur. Ranko Kovačević i sur. Maloljetnička delinkvencija - dijalog, razmjena iskustava i znanja, 1-33, Tuzla: OFF SET, 2017.; Nivex Koller-Trbović, Anja Mirosavljević i Ivana Jeđud Borić, Procjena potreba djece i mladih s problemima u ponašanju - konceptualne i metodičke odrednice (Zagreb: Ured UNICEF-a za Hrvatsku, 2017.); Lana Petö Kujundžić, „Prava djece u kaznenom maloljetničkom pravu prema međunarodnim i europskim standardima“, u: Novine u kaznenom zakonodavstvu, Zbornik radova, Opatija; (2017): 13-24 (bez navođenja urednika); Maja Vučić Blažić, Prema standardizaciji kriterija za izricanje odgojnih mjera počiniteljima kaznenih djela na primjeru upućivanja u disciplinski centar, Završni specijalistički rad (Rijeka: Sveučilište u Rijeci, 2020).

2 Carić, Kustura, Kamo ide hrvatsko maloljetničko kazneno zakonodavstvo, 605-620.

3 Daniel Mears, „Sentencing Guidelines and the Transformation of Juvenile Justice in the 21st Century“", Journal of Contemporary Justice 18, br. 1 (2002): 6-19; New Jersey Code, Purposes, 2009., pristup 16. siječnja 2020., https://law.justia.com/codes/new-jersey/2009/ title2a/2a-4a-21; Jean Zermatten, The best Interests of the Child. Literal Analysis, Function and Implementation, Working Report (Bramois, Institut international des droits de l'enfant, 2009); Frieder Dunkel, ,Juvenile Justice Systems in Europe - reform developments between justice, welfare and new punitivness", Kriminologijos studios br. 1 (2014): 31-76, DOI: 10.15388/ CrimLithuan.2014.0.3676.

4 Zakon o sudovima za mladež, Narodne novine, br. 84/11., 143/12., 56/15. i 126/19. (dalje: $\mathrm{ZSM} / 11)$.

5 Čl. 7. ZSM/11 propisuje vrste odgojnih mjera, a čl. 8. ZSM/11 propisuje kriterije za izricanje odgojnih mjera.

6 Čl. 6. ZSM/11.

7 Čl. 41. KZ/11., Kazneni zakon, Narodne novine, br. 125/11., 144/12., 56/15., 61/15., 101/17., 118/18., 126/19. 
prikupiti potrebne podatke. Članak 8. Zakona o sudovima za mladeži, propisuje što sud uzima u obzir (dalje: kao kategorije podataka navode se): 1. maloljetnikova dob, 2. njegova psihofizička razvijenost i osobine, 3. težina i narav počinjenoga djela, 4. pobude iz kojih i okolnosti u kojima je djelo počinio, 5. ponašanje nakon počinjenog djela i osobito je li, ako je to mogao, pokušao spriječiti nastupanje štetne posljedice ili nastojao popraviti počinjenu štetu, 6. odnos prema oštećeniku i žrtvi, 7. njegove osobne i obiteljske prilike, 8. je li i prije činio kaznena djela, 9. je li mu već bila izrečena maloljetnička sankcija i 10. sve druge okolnosti koje utječu na izbor takve odgojne mjere kojom će se najbolje ostvariti svrha odgojnih mjera. Sve navedene podatke (u svakoj kategoriji) sud prikuplja i pribavlja u obliku izvješća iz tri glavna izvora: nadležnoga centra za socijalnu skrb $^{8}$ te izvješća stručnog suradnika u državnom odvjetništvu i od stručnog suradnika na sudu za maloljetnike. ${ }^{9}$ Četvrti izvor, u hrvatskoj praksi znatno rjeđe korišten, odnosi se na timsku procjenu pri specijaliziranim odjelima u sustavu socijalne skrbi. ${ }^{10}$

Usporedbom zadataka i poslova navedenih triju glavnih izvora, proizlazi da je centar za socijalnu skrb glavni i terenski generator potrebnih i zakonom propisanih (kategorija) podataka koji, nakon zaprimljene obavijesti o postupanju državnog odvjetnika, obavlja potrebne razgovore i pribavlja informacije o maloljetniku i njegovom okružju. S druge strane, kod opisa poslova stručnoga suradnika izvan pravne struke u državnom odvjetništvu i na sudu, naglasak je na procjeni kriminogenih i zaštitnih čimbenika maloljetnika na osobnom, obiteljskom i školskom planu, iako nije isključeno niti terensko prikupljanje dodatnih podataka. Svi su navedeni izvori dužni sastaviti svoja izvješća.

Međutim, ne postoji podzakonski propis ili barem vodič, koji bi precizirao koja vrsta podataka u svakoj od 10 spomenutih kategorija treba prikupiti centar za socijalnu skrb. One su opisane toliko uopćeno da autoru izvješća otvaraju široke margine za diskrecijski odabir elementa koji će činiti izvješće.

Pretpostavka je da se zakonodavac takvim oblikovanjem kategorija potrebnih podataka najvećim dijelom oslanja na samorazumljive kompetencije stručnjaka izvan pravne struke koji sastavljaju izvješća. Autorice ne dovode u pitanje kompetencije spomenutih stručnjaka već, zbog nedostatka (ako ne propisane, onda barem dogovorene) hijerarhijske strukture podataka po važnosti, vide propust u dijelu organizacije procesa prikupljanja podataka i sastavljanja izvješća.

Dosadašnji rezultati znanstvenih i stručnih analiza izvješća centara za socijalnu skrb, posljednjih četrdesetak godina gotovo se ne razlikuju i poražavajući su. Bez iznimke, pružaju dokaze o tome da su izvješća štura, da im nedostaju bitne, ali obiluju nebitnim informacijama, da nema obrazloženoga prijedloga odgojne mjere i slažu se da podatci nisu organizirani u koherentni sklop, što može dovesti do izricanja

8 Čl. 78. st. 2. ZSM/11.

9 Čl. 43. st. 2. i 3. ZSM/11. te Pravilnik o radu stručnih suradnika izvan pravne struke na poslovima delinkvencije mladih i kaznenopravne zaštite djece u državnim odvjetništvima i na sudovima, čl. 5. toč. 8. i čl. 7. toč. 1. Pravilnika.

10 Čl. 78. st. 4. ZSM/11. 
neodgovarajuće sankcije. ${ }^{11}$ Novije istraživanje ${ }^{12}$ bavilo se analizom strukture izvješća centara za socijalnu skrb sastavljana za potrebe suda. Na provjernoj listi od 149 mogućih, unaprijed zadanih potrebnih ili preferiranih podataka, dobiveno je da je sudovima za mladež, u prosjeku, podastrta tek četvrtina takvih informacija bez obzira na to kojoj zakonskoj kategoriji pripadaju.

$\mathrm{U}$ radu, na istom uzorku, analizira se kakva je popunjenost (tako slabo informativnih izvješća) u svakoj od deset zakonski navedenih kategorija podataka.

Izvješća se, u pravilu, temelje na neformalnim procjenama (trenutačno kazneno djelo, ranija dokumentacija ako postoji, razgovor s počiniteljem u kontroliranim uvjetima), koje nemaju dobru valjanost. ${ }^{13}$ Ona često ne pružaju procjene o tome kakve su potrebe maloljetnika u smislu postizanja svrhe izricanja odgojne mjere, koja najčešće nije niti predložena. Taj tradicionalni pristup snažno naginje subjektivizmu i proizvoljnosti te stavlja sud u situaciju da sam pronalazi red i strukturu među informacijama. Sud se, naravno, rukovodi normativnim modelom donošenja odluke (favoriziranje alternative u kojoj je rizik donošenja pogrešne odluke minimalan). ${ }^{14}$ Istodobno je, posebno kod maloljetničkih predmeta, snažno izložen i deskriptivnom modelu. Uz to, kako su istraživanja pokazala, ${ }^{15}$ na suce utječu i izvanpravni čimbenici donošenja odluka. Neke od studija ${ }^{16}$ pokazale su da su suci nerijetko pod utjecajem irelevantnih čimbenika, te da ima i onih kojima adolescentski razvoj nije važan pa su

11 Vidi: Mladen Singer, Konstantin Momirović i Vojislav Kovačević, „Kriteriji sudova pri izricanju sankcija maloljetnicima“, Defektologija 12, br. 1-2 (1976): 48-121; Nivex Koller-Trbović, Anja Mirosavljević i Ivana Jeđud Borić, Procjena potreba djece i mladih s problemima u ponašanjukonceptualne $i$ metodičke odrednice (Zagreb: Ured UNICEF-a za Hrvatsku, 2017.); Marija Koren Mrazović, Maloljetnici i mlađi punoljetnici s poremećajima u ponašanju u tretmanu socijalne skrbi u Republici Hrvatskoj 6, № 2 (1998.), 141-152; Gordana Lulić Čavar, „Neki aspekti evaluacije učinkovitosti tijeka izvršenja odgojne mjere upućivanja u disciplinski centar za maloljetnike“, Kriminologija i socijalna integracija 3, br. 1 (1995): 53-70; Đurđa Križ, „Kriteriji za odabir odgojnih mjera maloljetnicima u svjetlu primjene Zakona o sudovima za mladež“, Hrvatski ljetopis za kazneno pravo i praksu 6, br. 2 (1999): 366-368; Dalida Rittossa i Melita Božićević Grbić, „Zakon o sudovima za mladež - reformski zahvati i praktične dileme“, Hrvatski ljetopis za kazneno pravo i praksu 19 br. 2 (2012): 615-667; Melita Božićević Grbić, Mirta Kuharić, Zakon o sudovima za mladež - primjena u praksi, Priručnik za polaznike/ice, (Zagreb: Pravosudna akademija, 2017.); Ivana Radić, „Hrvatski sustav maloljetničkih sankcija: trenutačno stanje i prijedlozi za promjenu“", Hrvatski ljetopis za kaznene znanosti i praksu 24, br. 1 (2017): 3-115.

12 Ljiljana Mikšaj-Todorović i Maja Vučić Blažić, „Kriteriji za izricanje odgojnih mjera“, Zbornik Pravnog fakulteta Sveučilišta u Rijeci 41, br. 2 (2020): 445-465.

13 Frank P. Williams III, Marilyn D. McShanew i H. Michael Dolny, „Developing a parole classification instrument for use as a management tool“, Corrections Management Quarterly 4, br. 4 (2000): 45-59; Neven Ricijaš, „Instrumenti procjene djece i adolescenata-mogućnosti primjene kod probacije za maloljetnike", Ljetopis socijalnog rada 13, br. 2 (2006): 271-295.

14 Više u: Marina Ajduković, „Psihologijski aspekti donošenja odluka u kaznenom postupku“, Hrvatski ljetopis za kazneno pravo i praksu 2 (1995): 292-307.

15 Ajduković, Psihologijski aspekti donošenja odluka u kaznenom postupku, 292-307.

16 John Zhuang Liu i Xueyao Li, ,Legal Techniques for Rationalizing Biased Judicial Decisions: Evidence from Experiments with Real Judges“, Journal of Empirical Legal Studies 16, br. 3 (2019): 630-670. 
u potrebi za daljnjim obrazovanjem. ${ }^{17}$

Moderni, znanstveno utemeljeni pristupi uključuju formalne procjene u kojima se, u konačnici, definiraju rizici i potrebe konkretnoga maloljetnika. Riječ je o kombinaciji kliničkog $\mathrm{i}$ aktuarskog pristupa ${ }^{18}$ i njima pripadajućim instrumentima. Tako, primjerice kanadski ${ }^{19} \mathrm{i}$ japanski ${ }^{20}$ korekcijski sustavi prihvaćaju procjene rizika i potreba temeljene na kombinaciji opservacije i primjene unaprijed dogovorenih instrumenata. Završno izvješće za potrebe suda usustavljeno je i temeljeno na definiranim procedurama za izradu svake, a onda i završne procjene te obuhvaća argumentirani prijedlog odgojne mjere. Instrumenti su procjene brojni, stalno se razvijaju i uključuju klasifikaciju delinkvenata uzimajući u obzir tretmanske potrebe, te rizike i predikciju budućega ponašanja, a koriste se u kombinaciji s opservacijom $u$ propisanim koracima. $^{21}$

Tradicionalnim, deskriptivnim i arbitrarnim načinom prikupljanja podataka centara za socijalnu skrb (koji su prema spomenutim analizama, uz to i manjkavi) stručni suradnici izvanpravne struke u državnom odvjetništvu i na sudu trebali bi procjenjivati kriminogene i zaštitne čimbenike, ${ }^{22}$ iako niti za njih ne postoji vodič o načinu te procjene te se proces svodi na nove $\mathrm{i}$ arbitrarne deskriptivne procjene. Stoga je opravdana pretpostavka da maloljetni počinitelji kaznenih djela u kaznenom postupku nisu tretirani jednako što upućuje na nepoštovanje prava svakoga maloljetnika na jednak postupovni pristup kao sastavnoga dijela načela prava na pravično suđenje.

Nedostatak navedenoga snažno se odražava na rad institucija koje provode odgojne mjere, jer one za potrebe tretmana pojedinoga maloljetnika, osim odluke suda, zaprimaju i izvješće centra za socijalnu skrb, ali ne i procjene potreba i rizika koje je načinio (ili trebao načiniti) stručni suradnik izvanpravne struke. Te institucije, dakle, same moraju prikupiti podatke koji nedostaju te procjenjivati potrebe i rizike čime se oduzima vrijeme za izradu individualnoga programa postupanja tijekom provođenja odgojnih mjera.

Svrha je ovog rada, na temelju rezultata provedenog istraživanja, procijeniti

17 Colleen M. Berryessa i Jillian Reeves, „The Perceptions of Juvenile Judges Regarding Adolescent Development in Evaluating Juvenile Competency“, Journal of Criminal Law and Criminology 110, br. 3 (2020): 551.

18 Detaljnije Bonta, 1996., prema Gwen Robinson, „Risk and risk assessment“. U: U Moving Probation Forward, eds. Wing Hong Chui, Mike Nellis, 108-128. (London: Pearson PLC, 2003).

19 Kelly Hannah-Moffat, Criminogenic needs and the transformative risk subject: Hybridizations of risk/need in penalty, Punishment \& Society 7, br. 1 (2005): 29-51.

20 Masaru Takahashi, „Assessment of Juvenile offenders at juvenile Classification Homes in Japan. UN Asia and Far east Institute for the Prevention of Crime and the Treatment of Offendesr (UNAFEI)“, Resource material 78 (2009): 151-158.

21 Više u: Patricia Van Voorhis, Michael Braswell, David Lester, Correctional Counseling \& Rehabilitation, $4^{\text {th }}$ ed. (Cincinnati: Anderson Publishing 2000.); Rudolf Alexander, Jr., Counseling, Treatment and Intervention - Methods with Juvenile and Adult Offenders (Belmont: Brooks/Cole-Thomson learning, 2000.); Anthony Walsh, Correctional Assessment, casework \& Counseling, $4^{\text {th }}$ ed. (Alexandria: American Correctional Association, 2020.).

22 Čl. 6. i 7. Pravilnika o radu stručnih suradnika izvanpravne struke na poslovima delinkvencije mladih i kaznenopravne zaštite djece u državnim odvjetništvima i na sudovima, Narodne novine, br. 22/13.-369. 
primjenu jednakosti postupanja prema svakom maloljetniku radi osiguravanja pravičnog suđenja i jednakosti svih pred zakonom i s tim u vezi ponuditi konkretne izmjene zakonskih i donošenje podzakonskih propisa.

\section{CILJEVI RADA}

Nastavno na rezultate ranijih znanstvenih i stručnih analiza i njima utvrđene manjkavosti izvješća centara za socijalnu skrb sastavljenih radi pružanja podataka za potrebe suda pri izricanju odgojne mjere, ciljevi ovog rada su:

1. utvrditi vrstu i količinu podataka u izvješćima centara za socijalnu skrb $\mathrm{s}$ obzirom na svaku od 10 kategorija podataka koje, prema čl. 8. Zakona o sudovima za mladež, ${ }^{23}$ sud uzima u obzir pri donošenju odluke o odgojnoj mjeri,

2. procijeniti primjenu jednakosti $u$ postupovnom pristupu prema svakom maloljetniku radi osiguravanja pravičnog suđenja i jednakosti svih pred zakonom u fazi procjene ${ }^{24}$ te

3. ponuditi konkretne izmjene zakonskih i donošenje podzakonskih propisa.

\section{METODOLOGIJA}

\subsection{Uzorak}

Uzorak ( $\mathrm{N}=59)$ čine maloljetni počinitelji kaznenih djela, na provođenje odgojnih mjera upućivanja u disciplinski centar upućeni u razdoblju od 1. siječnja 2016. do 31. prosinca 2018. na području nadležnosti Općinskog suda u: Čakovcu, Karlovcu, Koprivnici, Osijeku, Velikoj Gorici, Zagrebu, Sisku te Županijskog suda u Velikoj Gorici i Zagrebu. Izvor podataka je dokumentacija (izvješća centara za socijalnu skrb).

\subsection{Mjerni instrument}

Za potrebe istraživanja kreiran je upitnik pod nazivom Analiza dokumentacije korištene u postupku predlaganja odgojnih mjera maloljetnicima (APOM). ${ }^{25} \mathrm{~S}$ obzirom na ciljeve rada, u korištenom instrumentu pozornost je usmjerena na vrstu i kvantiteti prikupljenih podataka. U ovom se radu koriste ukupno 142 varijable preuzete iz navedenog instrumenta i to na način da svakoj od 10 zakonskih kategorija pripada odgovarajući broj varijabli, vidljiv u prvom stupcu tablice 1 . Nazivi pojedinih

23 Zakon o sudovima za mladež, Narodne novine, br. 126/19.

24 Međunarodni akti, posebno Konvencija o pravima djeteta (čl. 3. st. 1. i 2.) zahtijeva poštovanje najboljeg interesa djeteta, a maloljetničko sudovanje zahtijeva poštovanje i ostalih načela $u$ postupanju prema maloljetnicima. Pritom se posebno ističe pravo djeteta na pravično suđenje koja su propisana čl. 6. st. 1. Europske konvencije za zaštitu ljudskih prava i temeljnih sloboda, čl. 14. st. 1. Međunarodnog pakta o građanskim i političkim pravima, kao i čl. 29. st. 1. Ustava RH. Navedeno propisuje i čl. 11. st. 1. ZKP/08, a čl. 26. Ustava RH osigurava građanima da su svi pred zakonom jednaki.

25 Instrument, njegove cjeline i racionala opisani su u Mikšaj-Todorović i Vučić Blažić, Kriteriji za izricanje odgojnih mjera: 445-465. 
varijabli u svakoj od deset kategorija vidljivi su iz tabličnih i grafičkih prikaza rezultata istraživanja.

\subsection{Metode obrade podataka}

U radu je korišten program Microsoft Office Excel za obradu i analizu primarnih podataka. Prikupljeni podatci analizirani su primjenom metoda deskriptivne statističke analize (računanje apsolutnih i relativnih frekvencija i prosjeka) i prikazani tablično i grafikonima.

\section{REZULTATI I RASPRAVA}

Prvi je cilj rada bio utvrditi vrstu i količinu podataka koje izvješća centara za socijalnu skrb sadrže u svakoj od zakonom ${ }^{26}$ definiranih 10 kategorija.

$\mathrm{Na}$ istom je uzorku, nedavno istraživanje ${ }^{27}$ pokazalo da je, od ukupnog broja traženih podataka bez obzira na razvrstanost u kategorije, prosječno u izvješćima bila prisutna tek četvrtina.

U tablici 1. dan je usporedni prikaz popunjenosti izvješća u svakoj od 10 zakonskih kategorija kod najbolje popunjenog izvješća, najslabije popunjenog izvješća te prosjeka popunjenosti ostalih izvješća.

Tablica 1. Popunjenost izvješća $(\mathrm{N}=59)$ u svakoj od 10 zakonski definiranih kategorija

\begin{tabular}{|l|l|l|l|l|}
\hline Sud će uzeti u obzir. & Broj** & $\begin{array}{l}\text { Najbolje } \\
\text { popunjeno } \\
\text { izvješce (1) }\end{array}$ & $\begin{array}{l}\text { Ostala } \\
\text { izvješća } \\
(57)\end{array}$ & $\begin{array}{l}\text { Najlošije } \\
\text { popunjeno } \\
\text { izvješće (1) }\end{array}$ \\
\hline (1) maloljetnikovu dob, & 1 & $100 \%$ & $93 \%$ & $100 \%$ \\
\hline (2) njegovu psihofizičku razvijenost i osobine, & 49 & $65,3 \%$ & $12 \%$ & $0,0 \%$ \\
\hline (3) težinu i narav počinjenoga djela, & 1 & $100 \%$ & $52,6 \%$ & $0,0 \%$ \\
\hline $\begin{array}{l}\text { (4) pobude iz kojih i okolnosti u kojima je djelo } \\
\text { počinio }\end{array}$ & $0^{*}$ & $0,0 \%$ & $0,0 \%$ & $0,0 \%$ \\
\hline $\begin{array}{l}\text { (5) ponašanje nakon počinjenog djela i osobito } \\
\text { je li, ako je to mogao, pokušao spriječiti } \\
\text { nastupanje štetne posljedice ili nastojao } \\
\text { popraviti počinjenu štetu }\end{array}$ & 6 & $66,67 \%$ & $16,7 \%$ & $0,0 \%$ \\
\hline $\begin{array}{l}\text { (6) odnos prema oštećeniku i žrtvi } \\
\text { (7) njegove osobne i obiteljske prilike }\end{array}$ & 21 & $100 \%$ & 51,6 & $0,0 \%$ \\
\hline (8) je li i prije činio kaznena djela & 1 & $100 \%$ & 63,2 & $0,0 \%$ \\
\hline $\begin{array}{l}\text { (9) je li mu već bila izrečena maloljetnička } \\
\text { sankcija }\end{array}$ & 1 & $100 \%$ & 57,9 & $0,0 \%$ \\
\hline $\begin{array}{l}\text { (10) sve druge okolnosti koje utječu na izbor } \\
\text { takve odgojne mjere kojom će se najbolje } \\
\text { ostvariti svrha odgojnih mjera }\end{array}$ & 62 & $82,5 \%$ & $23,5 \%$ & $6,3 \%$ \\
\hline Ukupno varijabli & 142 & $71,45 \%$ & $37 \%$ & $10,63 \%$ \\
\hline
\end{tabular}

* kategorije 4 i 6 nemaju predviđenu niti jednu varijablu jer niti u jednom od analiziranih izvora nikakav podatak u tom smislu nije postojao

26 Zakon o sudovima za mladež, Narodne novine, br. 84/11., 143/12., 56/15., 126/19.

27 Mikšaj-Todorović i Vučić Blažić, Kriteriji za izricanje odgojnih mjera: 445-465. 
** broj varijabli u svakoj zakonskoj kategoriji

Iz tablice 1. vidljivo je da sud za maloljetnike, iz izvješća centara za socijalnu skrb, ne raspolaže podatcima o okolnostima i pobudama iz kojih je djelo počinjeno kao niti o odnosu počinitelja prema oštećeniku i/ili žrtvi. U neznatnom broju slučajeva raspolaže informacijama o ponašanju maloljetnika neposredno nakon počinjenog djela, što je pobliže objašnjeno u potpoglavlju 4.5. To je razumljivo $s$ obzirom na to da bi ulazak u tu tematiku centra za socijalnu skrb bila povreda načela nemo tenetur se ipsum accusare, odnosno, prava maloljetnika na uskratu iskaza i uskratu suradnje $\mathrm{s}$ državnim tijelima u kaznenom postupku protiv sebe..$^{28}$

U svakoj od ostalih kategorija, najbolje ispunjeno izvješće pruža između dvije trećine i svih predviđenih / potrebnih podataka. U najlošije ispunjenom izvješću zakonskih propisanih podataka gotovo da i nema. Kod preostalih izvješća, kad se izuzmu kategorije 1, 4, 5 i 6, popunjenost svake od kategorija kreće se u rasponu od $12 \%$ do $66,7 \%$.

Već ovaj letimičan pregled po zakonskim kategorijama ukazuje na subjektivitet i nejednako postupanje u procesu prikupljanja podataka te na potrebu strukturiranja izvješća. Slijedi analiza broja i vrste podataka u svakoj od zakonski definiranih kategorija.

\subsection{Popunjenost izvješća u kategoriji maloljetnikova dob-kategorija 1.}

Iako je maloljetnikova dob formalni podatak koji je uobičajeno, prisutan u većini formalnih dokumenata o pojedincu, a kod suda za maloljetnike izrijekom je naveden kao potreban podatak, zanimljivo je da u $7 \%$ ostalih izvješća on uopće nije naveden (tablica 1.). Trebalo ga je, dakle, naknadno pronaći kako bi sud njime raspolagao.

\subsection{Popunjenost izvješća unutar kategorije psihofizička razvijenost i osobine maloljetnika - kategorija 2.}

S obzirom na to da se izvješća u pravilu sastavljaju neformalnim procjenama, provjerom listom obilježja psihofizičke razvijenosti i osobina maloljetnika, obuhvaćena su ona koja su, prema istraživanjima, od etiološkog, tretmanskog i prediktivnoga značaja. Riječ je o ukupno 49 varijabli, organiziranih u tri potkategorije: 1. opća obilježja (29 varijabli), 2. stavovi / odnosi (13 varijabli) i 3. interesi (7 varijabli).

\subsubsection{Opća obilježja - potkategorija kategorije (2)}

Najbolje izvješće u kategoriji općih obilježja obuhvaćalo je 21 od 29 predviđenih obilježja. U njemu su izostavljeni podatci o: odlasku na počinak, organiziranosti tijekom učenja, slici o sebi i svom fizičkom izgledu te spremnosti na pružanje i primanje pomoći. Najlošije izvješće nije obuhvaćalo niti jedan od 29 očekivanih podataka.

28 Igor Bojanić i Zlata Đurđević, „Dopuštenost uporabe dokaza pribavljenih kršenjem temeljnih ljudskih prava“, Hrvatski ljetopis za kazneno pravo i praksu 15, br. 2 (2008): 973-1003. 
Prosječna popunjenost potkategorije opća obilježja u ostalim izvješćima, prikazana je grafikonom 1 .

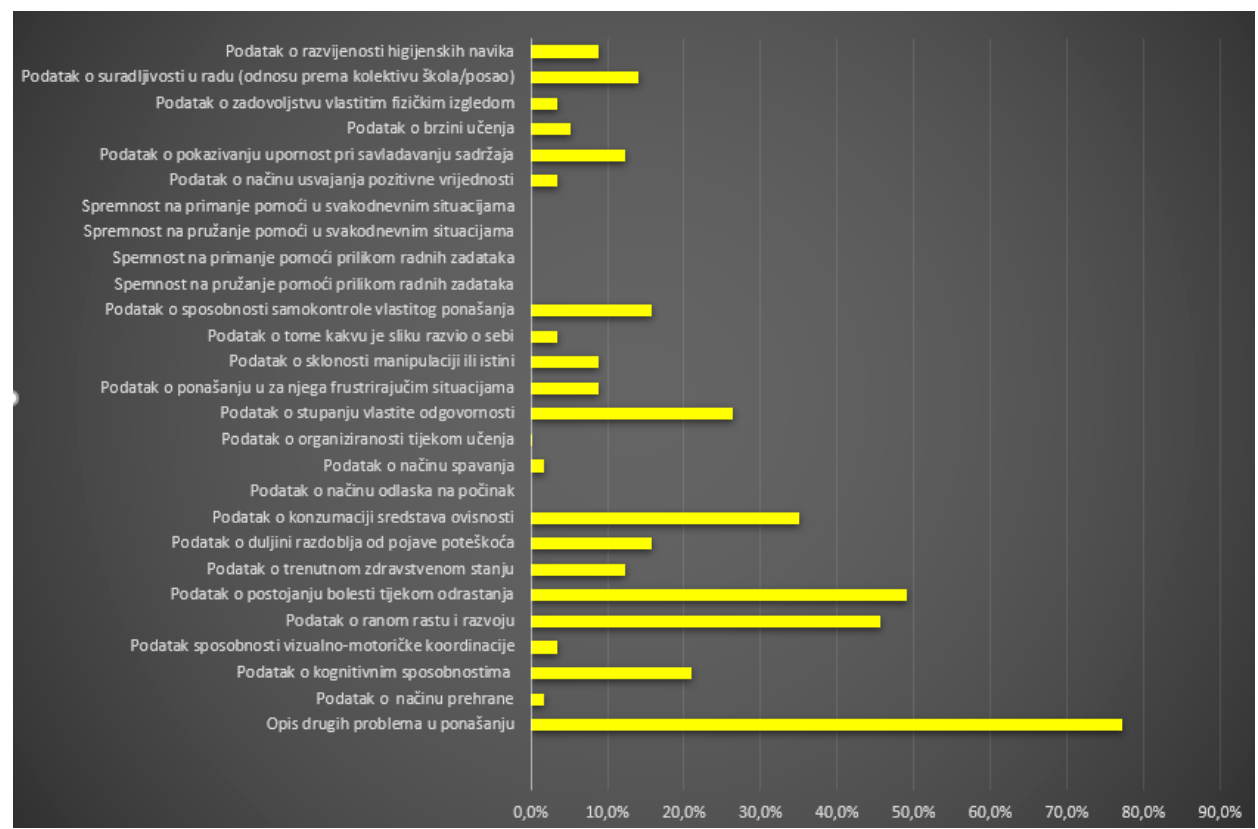

Grafikon 1. Opća obilježja - potkategorija kategorije 2. (ostala izvješća)

Prosječna popunjenost potkategorije opća obilježja je svega 13,2 \% očekivanih podataka. Iz grafikona 1. vidljivo je da o načinu odlaska na počinak (kao elementa procjene urednosti rutine) te o spremnosti na pružanje i primanje pomoći u radnom i svakodnevnom okružju nema informacija niti u jednom izvješću, iako to mogu biti važni pokazatelji potreba u funkciji tretmana. Relativno najviše informacija u ovoj potkategoriji zamijećeno je kad su u pitanju: opis drugih problema u ponašanju $(77,2$ $\%)$, bolesti tijekom odrastanja $(49,1 \%)$, podatak o ranom rastu i razvoju $(45,6 \%)$ te podatak o konzumaciji sredstava ovisnosti $(35,1 \%)$.

\subsubsection{Stavovi / odnosi-potkategorija kategorije 2.}

Drugu potkategoriju kategorije 2., čine stavovi / odnos prema sebi, drugima i vrijednostima. Provjerna lista sadrži 13 takvih varijabli vidljivih u grafikonu 2.

Čak niti najbolje ispunjeno izvješće nije uzelo u obzir da bi stavovi ili odnos prema vlastitim osobinama, vlastitoj imovini, duhovnim vrijednostima, vlastitoj budućnosti te prema odraslima i suprotnom spolu, mogli biti bitni za konačnu sliku o maloljetniku. Najlošije ispunjeno izvješće ništa od svih predviđenih stavova / odnosa nije smatralo relevantnim za upoznavanje osobina maloljetnika.

Grafikonom 2. prikazan je prosjek popunjenosti ostalih izvješća na 13 varijabli stavova / odnosa. 


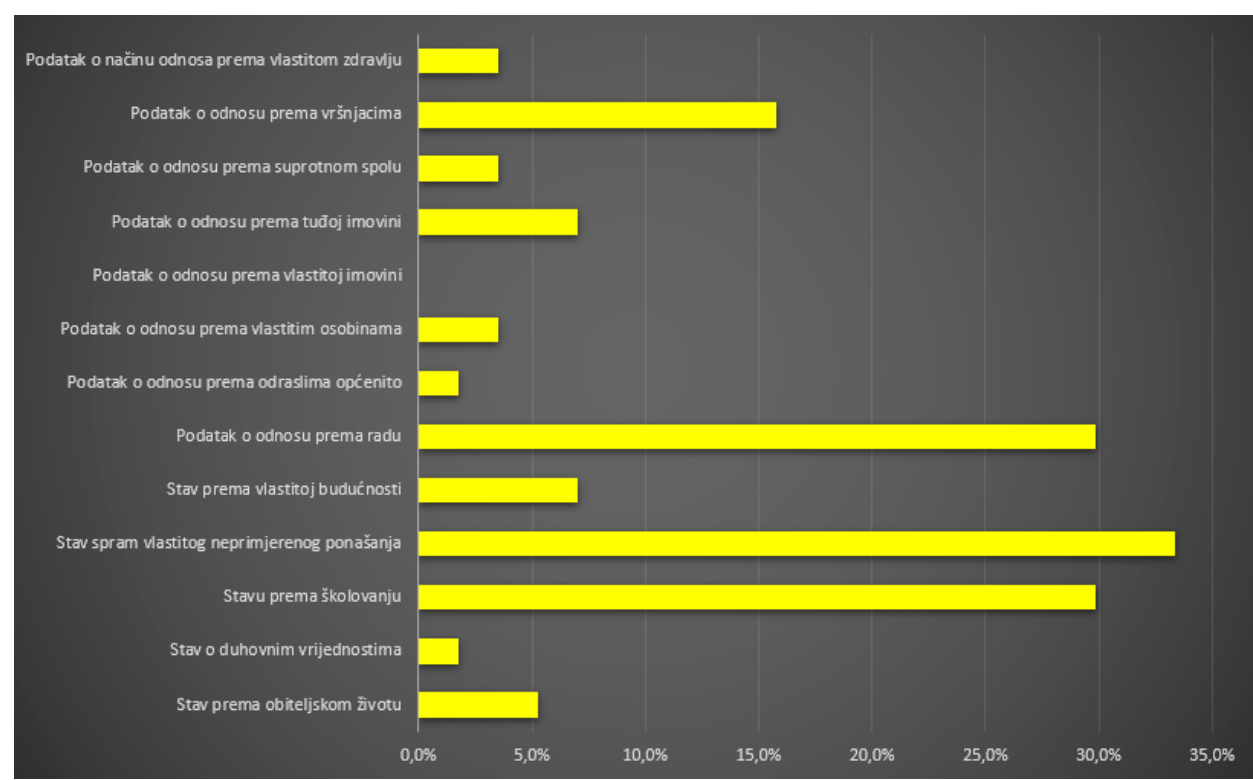

Grafikon 2. Stavovi / odnosi - potkategorija kategorije 2. (ostala izvješća)

Iz grafikona 2. vidljivo je da su u ostalim izvješćima najčešće prikupljeni podatci o stavu prema vlastitom neprimjerenom ponašanju, školovanju i radu, dok su ostali podatci prikupljeni u manjem opsegu, mnogi tek sporadično.

\subsubsection{Interesi-potkategorija kategorije 2.}

Treća potkategorija kategorije 2. odnosi se na interese maloljetnika važnih za odabir odgojne mjere i tretmanske intervencije. Njih na provjernoj listi opisuje sedam varijabli (grafikon 3).

Najbolje ispunjeno izvješće nije se pozivalo na interese maloljetnika za tehničke aktivnosti, prirodu i društvena zbivanja, no u nekim drugim izvješćima ti podatci postoje. Najlošije ispunjeno izvješće nije se referiralo na interese.

Grafikonom 3. prikazane su prosječne vrijednosti popunjenosti ostalih izvješća. 


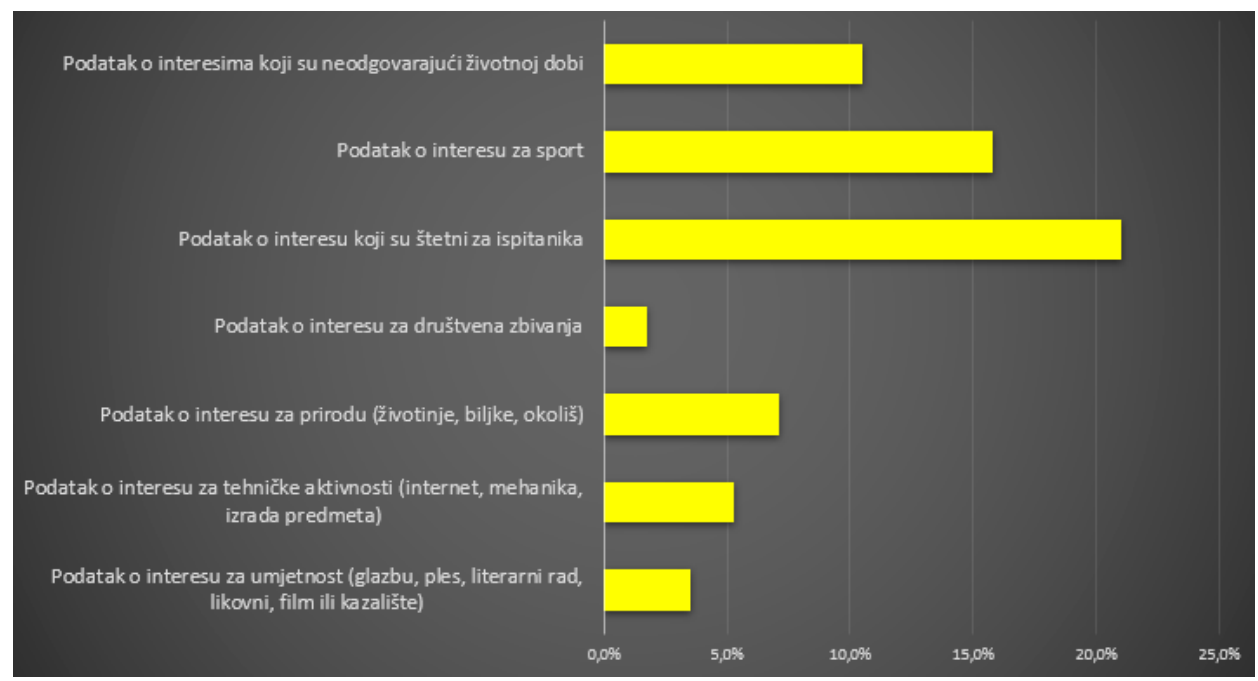

Grafikon 3. Interesi - potkategorija kategorije 2. (ostala izvješća)

Izvješća prosječno pružaju tek $9,3 \%$ podataka o interesima u odnosu na očekivane odgovore. Pritom je, prosječno najčešće prisutan podatak o interesima štetnim za ispitanika $(21,1 \%)$ i za sport (15,8 \%). Podatak o interesu za društvena zbivanja obuhvaća samo jedno izvješće.

Iz analize svih triju potkategorija u kategoriji 2. koje opisuju psihofizičku razvijenost i osobine maloljetnika, kad se izuzme najbolje ispunjeno izvješće, može se zaključiti da je ova kategorija vrlo slabo opisana u izvješćima centra za socijalnu skrb te da ona pružaju pojedine podatke prema nepoznatom kriteriju.

\subsection{Popunjenost izvješća unutar kategorije težina i narav počinjenog djela - kategorija 3.}

Sva analizirana izvješća vrlo sporadično spominju samo kazneno djelo, najčešće samo navođenjem njegovog naziva i katkad, opisa provođenja. Opisi težine i naravi djela u širem smislu, nisu pronađeni. Tako se u ovoj kategoriji analizira samo jedna varijabla koja se odnosi bilo na kakav spomen kaznenog djela. On je prisutan u najbolje popunjenom izvješću, u najlošijem nedostaje, a prosječna popunjenost ostalih izvješća povezana s bilo kakvim podatkom o kaznenom djelu iznosi 52,6 \% (tablica 2).

Tablica 2. Navođenje i/ili opis kaznenog djela

\begin{tabular}{|l|l|l|l|}
\hline & $\begin{array}{l}\text { Najbolje popunjeno } \\
\text { izvješće }\end{array}$ & $\begin{array}{l}\text { Prosjek popunjenosti ostalih } \\
\text { izvješća }\end{array}$ & $\begin{array}{l}\text { Najlošije popunjeno } \\
\text { izvješće }\end{array}$ \\
\hline $\begin{array}{l}\text { Popunjeno: } \\
\text { Aps. \% }\end{array}$ & $100,00 \%$ & $52,6 \%$ & $0,00 \%$ \\
\hline
\end{tabular}

Narav djela, ili detalji koji bi ukazivali na neke druge važne poveznice sa samim djelom, izostali su u svim izvješćima. Razumljivo je da će centri za socijalnu skrb 
izbjegavati detaljnije bavljenje kaznenim djelom jer će njegov opis i kvalifikaciju procijeniti pravne instance. Sve ostalo moglo bi dovesti u pitanje načelo nemo tenetur se ipsum accusore. ${ }^{29}$ Stoga je nužno razjasniti kakve se informacije u sklopu kategorije 3. očekuju u izvješćima centara za socijalnu skrb.

\subsection{Popunjenost izvješća u kategoriji pobude iz kojih i okolnosti u kojima je djelo počinio - kategorija 4.}

U svim analiziranim izvješćima nije se pronašao niti jedan podatak koji bi makar indicirao pobude iz kojih i okolnosti u kojima je maloljetnik djelo počinio. Ako je riječ o načelu nemo tenetur se ipsum accusare, to u nekoj vrsti naputka ili vodiča treba biti jasno naznačeno. Sud će do tih informacija doći pri ispitivanju maloljetnika i provođenja drugih dokaza.

\subsection{Popunjenost izvješća u kategoriji ponašanje nakon počinjenog djela, osobito ako je to mogao, pokušao spriječiti nastupanje štetne posljedice i nastojao popraviti počinjenu štetu - kategorija 5.}

Nema niti jednog izvješća koje bi se osvrnulo na sprječavanje nastupanja štetne posljedice i popravljanje počinjene štete jer bi se u protivnom moglo raditi o povredi načela nemo tenetur se ipsum accusare. Ako i postoje informacije o ponašanju maloljetnika nakon počinjenog djela, one se odnose na njegovu suradljivost tijekom razgovora i stav prema kaznenom djelu i djelima općenito i razvrstane su u 6. varijabli (grafikon 4.).

Najbolje ispunjeno izvješće obuhvaća četiri takva podatka, a najslabije izvješće ne obuhvaća niti jedan od tih podataka.

29 Hrv. Nitko nije dužan sam sebe optuživati. Navedena izreka sadržava pravilo prema kojem u sudskom postupku nitko nije dužan protiv sebe iznositi činjenice ili okolnosti koje bi mu mogle škoditi te se protiv takve osobe ne mogu u tom slučaju poduzimati nikakve prisilne mjere, vidi u: Marko Petrak, „Kanonsko pravo i hrvatski pravni sustav (I). Pravni izvori i pravna načela“, Zbornik Pravnog fakulteta u Zagrebu 70, br. 2-3 (2020): 251-286, 264. 


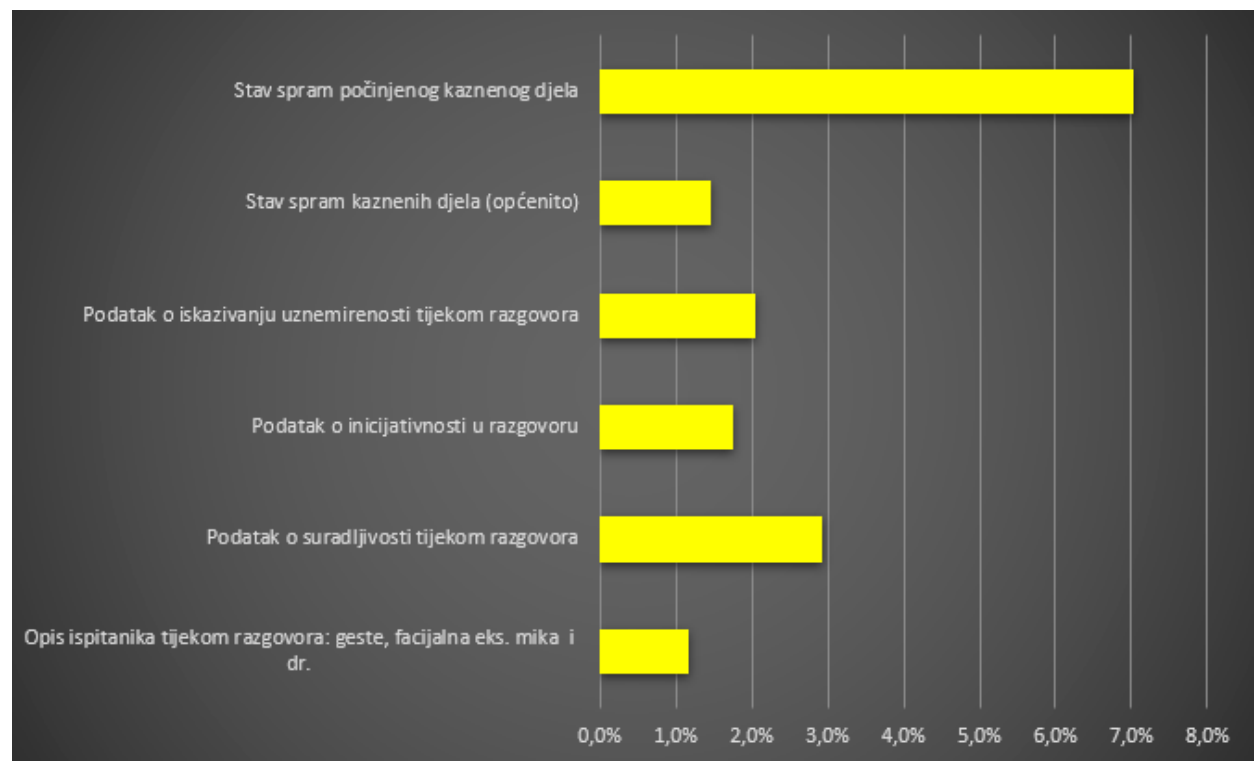

Grafikon 4. Ponašanje nakon počinjenog djela - kategorija 5. (ostala izvješća)

U ostalim izvješćima, bilo kakva ponašanja maloljetnika nakon počinjenoga kaznenog djela spominju se sporadično, a najčešće je to stajalište spram počinjenoga kaznenog djela zbog kojeg je trenutačno u postupku i to samo u 7 \% slučajeva. Prvo je pitanje je li ispitivanje toga stajališta djelatnika centra za socijalnu skrb povreda načela nemo tenetur se ipsum accusare, a drugo, koja je svrha opisa suradljivosti maloljetnika tijekom razgovora.

\subsection{Popunjenost izvješća unutar kategorije odnos prema oštećeniku i žrtvi - kategorija 6.}

U izvješćima centara za socijalnu skrb nije bilo podataka koji su se odnosili na ovu kategoriju vjerojatno zbog moguće povrede načela nemo tenetur se ipsum accusare.

\subsection{Popunjenost izvješća u kategoriji njegove osobne i obiteljske prilike-kategorija 7 .}

Obiteljske prilike mogu se relativno dobro procijeniti kroz višekratno komuniciranje s obitelji, posebno u obiteljskom okružju. No, različiti sastavljači izvješća uvrštavaju različite informacije iz obiteljskog života (tablica 3.). Na 21 obilježju obiteljskih prilika iz provjerne liste (tablica 3.), popunjenost ostalih izvješća je tek $52 \%$.

Osobne prilike su širok i nedefiniran pojam, pritom je moguće da se dio informacija o njima krije u kategorijama 2. i 10. Tako se tablice 3. i 4. odnose samo na obiteljske prilike. Dalje u analizi, bolje je razrađena kategorija 10. koja bi se većim dijelom mogla odnositi na osobne prilike. 
Tablica 3. Obiteljske prilike

\begin{tabular}{|l|l|l|l|}
\hline $\begin{array}{l}\text { Njegove osobne i obiteljske } \\
\text { prilike }\end{array}$ & $\begin{array}{l}\text { Najbolje popunjeno } \\
\text { izvješće }\end{array}$ & $\begin{array}{l}\text { Prosjek popunjenosti } \\
\text { ostalih izvješća }\end{array}$ & $\begin{array}{l}\text { Najlošije } \\
\text { popunjeno izvješće }\end{array}$ \\
\hline Popunjeno: Aps \% & $100,00 \%$ & $52,00 \%$ & $0,00 \%$ \\
\hline
\end{tabular}

Iz tablice 3. vidljivo je da je najbolje popunjeno izvješće obuhvaćalo sve podatke iz provjerne liste. Nevjerojatnim se čini podatak da najlošije popunjeno izvješće nije obuhvaćalo niti jedan podatak o obiteljskim prilikama.

Tablica 4. Prosjek popunjenosti izvješća o obiteljskim prilikama (ostala izvješća)

\begin{tabular}{|l|l|}
\hline Varijabla & $\begin{array}{l}\text { Postotak } \\
\text { popunjenosti }\end{array}$ \\
\hline Podatak o odgojnom stilu roditelja & $28,1 \%$ \\
\hline Podatak o odgojnim kapacitetima roditelja & $40,4 \%$ \\
\hline Podatak o uključenosti roditelja u odgoj & $47,4 \%$ \\
\hline Podatak koji govori o stajalištu roditelja prema ispitaniku & $21,1 \%$ \\
\hline Opći podatak o braku roditelja & $86 \%$ \\
\hline Podatak o odnosu s majkom & $32,1 \%$ \\
\hline Podatak o tijeku poroda & $37,5 \%$ \\
\hline Podatak o odnosu s ocem & $33,9 \%$ \\
\hline Osnovni podatci o ocu & $92,9 \%$ \\
\hline Dopunski podatci o ocu & $78,6 \%$ \\
\hline Osnovni podatci o majci & $94,6 \%$ \\
\hline Dopunski podatci o majci & $80,4 \%$ \\
\hline Podatak o kvaliteti braka & $39,3 \%$ \\
\hline Podatak o ranijim intervencijama u obitelji & $71,4 \%$ \\
\hline Podatak o načinu na koji roditelji rješavaju probleme & $16,1 \%$ \\
\hline Osnovni podatci o ostalim članovima obitelji & $96,4 \%$ \\
\hline Podatak o suradljivosti roditelja spram djelatnika centra za socijalnu skrb & $28,6 \%$ \\
\hline Opis odnosa s ostalim članovima kućanstva & $23,2 \%$ \\
\hline Podatak o uključenosti ostalih članova obitelji u odgoj & $5,4 \%$ \\
\hline Podatak o stambenim prilikama & $85,7 \%$ \\
\hline Podatak o socioekonomskom statusu obitelji & $67,9 \%$ \\
\hline
\end{tabular}

Podatci o članovima obitelji i kućanstva, braku roditelja, stambenim prilikama i ranijim intervencijama u obitelj, prosječno su prisutni u relativno dobro. No, u nekim izvješćima oni nedostaju. O obiteljskoj atmosferi, odgojnim stilovima i odnosima među članovima obitelji malo je podataka (primjerice, tek u oko trećine slučajeva spominje se odnos s ocem i/ili majkom) u svjetlu uloge roditelja za procjenu zaštitnih ili rizičnih čimbenika.

Zaključno, o obiteljskim prilikama maloljetnika u izvješćima općenito postoje 
neki podatci, ali pretežu oni činjenični, dok je procjena kvalitete obiteljskog života u pravilu vrlo slabo prisutna.

\subsection{Popunjenost izvješća u kategoriji je li i prije činio kaznena djela - kategorija 8.}

Sud treba raspolagati točnom informacijom o tome je li maloljetnik ranije činio kaznena djela ili prekršaje, koja i pod kojim okolnostima. Bilo kakav spomen prethodno počinjenih djela ili prekršaja (ili bilješka da ranije nije činio kaznena djela/prekršaje) u ovoj se analizi smatraju postojećim podatkom o ranijem činjenju kaznenih djela ili prekršaja.

Iz tablice 5. proizlazi da je najbolje popunjeno izvješće taj podatak uključilo, a najlošije izvješće nije.

Tablica 5. Je li ranije činio kaznena djela

\begin{tabular}{|l|l|l|l|}
\hline $\begin{array}{l}\text { Podatak o ranijem činjenju } \\
\text { kaznenog / kaznenih djela ili } \\
\text { prekršaja }\end{array}$ & $\begin{array}{l}\text { Najbolje popunjeno } \\
\text { izvješće }\end{array}$ & $\begin{array}{l}\text { Prosjek popunjenosti } \\
\text { ostalih izvješća }\end{array}$ & $\begin{array}{l}\text { Najlošije } \\
\text { popunjeno izvješće }\end{array}$ \\
\hline Popunjeno: Aps \% & $100,00 \%$ & $63,2 \%$ & $0,00 \%$ \\
\hline
\end{tabular}

U ostalim izvješćima, na ranije kazneno djelo ili prekršaj osvrnulo se u tek $63 \%$ izvješća. Otvara se pitanje trebaju li taj podatak provjeravati centri za socijalnu skrb ili ju sud može dobiti iz evidencije Ministarstva rada, mirovinskog sustava, obitelji i socijalne politike.

\subsection{Popunjenost izvješća u kategoriji je li mu već bila izrečena maloljetnička sankcija - kategorija 9.}

Sud treba raspolagati točnom informacijom o tome je li maloljetniku ranije bila izrečena neka maloljetnička sankcija, koja i kakav je bio njezin ishod. Ovo će gledati u kontekstu ranije počinjenog kaznenog djela i/ili prekršaja ili više njih. Bilo kakav spomen o prethodno izrečenoj sankciji ili sankcijama (ili bilješka da takvih sankcija ranije nije bilo) u ovoj se analizi smatraju postojećim podatkom o ranijem činjenju kaznenih djela ili prekršaja.

Iz tablice 6. proizlazi da je najbolje popunjeno izvješće taj podatak uključilo, a najlošije izvješće nije.

Tablica 6. Je li mu već bila izrečena maloljetnička sankcija

\begin{tabular}{|l|l|l|l|}
\hline $\begin{array}{l}\text { Je li mu već bila izrečena } \\
\text { maloljetnička sankcija }\end{array}$ & $\begin{array}{l}\text { Najbolje popunjeno } \\
\text { izvješće }\end{array}$ & $\begin{array}{l}\text { Prosjek popunjenosti } \\
\text { ostalih izvješća }\end{array}$ & $\begin{array}{l}\text { Najlošije } \\
\text { popunjeno izvješće }\end{array}$ \\
\hline Popunjeno: Aps \% & $100,00 \%$ & $57,9 \%$ & $0,00 \%$ \\
\hline
\end{tabular}


U preostalim izvješćima, na ranije izrečene sankcije osvrnulo se tek 57,9\% izvješća. I ovdje se otvara pitanje trebaju li taj podatak provjeravati centri za socijalnu skrb ili ju sud može dobiti iz evidencije Ministarstva rada, mirovinskog sustava, obitelji i socijalne politike.

\subsection{Popunjenost izvješća u kategoriji sve druge okolnosti koje utječu na izbor odgojne mjere kojom će se najbolje ostvariti svrha odgojnih mjera - kategorija 10.}

Sintagma sve druge okolnosti obuhvaća široku lepezu mogućih informacija. Kad je provjerena lista sastavljana, uzete su u obzir i sve one informacije koje nisu izrijekom definirane u prvih devet zakonskih kategorija, a čine bitan korpus spoznaja o maloljetniku, njegovom okružju i što je najvažnije, o procedurama prema kojima je maloljetnik procjenjivan. Analizom izvješća, iskristaliziralo se pet jasnih potkategorija: 1. način procjene, 2. tijek školovanja, 3. slobodno vrijeme, 4. ranije intervencije prema maloljetniku i njihova učinkovitost te 5. prijedlog odgojne mjere i preporuke za tretman.

Iz tablice 7. vidljivo je da najbolje popunjeno izvješće, u odnosu na svih pet potkategorija, obuhvaća između $75 \%$ i $100 \%$ očekivanih podataka. U najlošije popunjenom izvješću, nema nikakvih informacija za četiri potkategorije, a nešto manje od petine očekivanih podataka nalazi se u potkategoriji školovanja.

Tablica 7. Prosječna popunjenost ostalih izvješća - kategorija 10.

\begin{tabular}{|l|l|l|l|l|}
\hline $\begin{array}{l}\text { Sve druge okolnosti koje utječu na } \\
\text { izbor takve odgojne mjere kojom } \\
\text { će se najbolje ostvariti svrha } \\
\text { odgojnih mjera }\end{array}$ & Broj varijabli & $\begin{array}{l}\text { Najbolje } \\
\text { popunjeno } \\
\text { izvješće }\end{array}$ & $\begin{array}{l}\text { Prosjek } \\
\text { popunjenosti } \\
\text { ostalih izvješća }\end{array}$ & $\begin{array}{l}\text { Najlošije } \\
\text { popunjeno } \\
\text { izvješće }\end{array}$ \\
\hline Način procjene & 21 & $81,0 \%$ & $13,6 \%$ & $0,0 \%$ \\
\hline Školovanje & 22 & $81,8 \%$ & $36,4 \%$ & $18,2 \%$ \\
\hline Slobodno vrijeme & 4 & $75,0 \%$ & $30,3 \%$ & $0,0 \%$ \\
\hline Ranije intervencije & 2 & $100 \%$ & $63,2 \%$ & $0,0 \%$ \\
\hline Predikcija & 13 & $93,3 \%$ & $15,2 \%$ & $0,0 \%$ \\
\hline Popunjenost & 62 & $86,22 \%$ & $31,74 \%$ & $3,64 \%$ \\
\hline
\end{tabular}

U ostalim izvješćima, popunjenost je raznolika u rasponu od 13,6 \% do 63,2 \%. Najprisutnije su informacije o ranijim intervencijama prema maloljetniku koje postoje u evidencijama centara za socijalnu skrb.

Slijedi analiza popunjenosti svake od pet potkategorija kategorije 10.

\subsubsection{Način procjene - potkategorija kategorije 10.}

Mjesto, vrijeme i način dolaska do svakoga činjeničnog podatka i svake procjene obilježja maloljetnika i njegovog okružja, važne su informacije radi osiguranja jednakosti postupka za sve maloljetnike s aspekta njihovog prava na isti tretman u ovoj 
etapi kaznenog postupka. Najbolje popunjeno izvješće obuhvaća detaljne podatke o načinu procjene, a nedostaju podatci o korištenju dvije vrste testova, jedne skale i vremenu procjene. Najlošije popunjeno izvješće ne obuhvaća niti jedan podatak o načinu procjene.

Tablica 8. Način procjene

\begin{tabular}{|l|l|l|l|}
\hline $\begin{array}{l}\text { Način procjene } \\
\text { Broj varijabli: } 21\end{array}$ & $\begin{array}{l}\text { Najbolje } \\
\text { popunjeno } \\
\text { izvješce }\end{array}$ & $\begin{array}{l}\text { Prosjek } \\
\text { popunjenosti } \\
\text { ostalih izvješća }\end{array}$ & $\begin{array}{l}\text { Najlošije } \\
\text { popunjeno } \\
\text { izvješce }\end{array}$ \\
\hline Podatak o mjestu procjene & $100 \%$ & $14,0 \%$ & $0,0 \%$ \\
\hline Vrsta procjene & $100 \%$ & $1,8 \%$ & $0,0 \%$ \\
\hline $\begin{array}{l}\text { Podatak o korištenju testova nedovršenih rečenica } \\
\text { socijalni pedagog }\end{array}$ & $0,0 \%$ & $1,8 \%$ & $0,0 \%$ \\
\hline Podatak o izvorima informacija & $100 \%$ & $63,2 \%$ & $0,0 \%$ \\
\hline Podatak o metodama i tehnikama procjene & $100 \%$ & $24,6 \%$ & $0,0 \%$ \\
\hline Podatak o primjeni skale/la procjene rizičnosti & $0,0 \%$ & $3,5 \%$ & $0,0 \%$ \\
\hline Podatak o provedbi psihološkog testiranja & $100 \%$ & $17,5 \%$ & $0,0 \%$ \\
\hline $\begin{array}{l}\text { Podatak o korištenim instrumentima procjene } \\
\text { psihologa }\end{array}$ & $100 \%$ & $10,5 \%$ & $0,0 \%$ \\
\hline Podatak o korištenju skala samopoimanja & $100 \%$ & $3,5 \%$ & $0,0 \%$ \\
\hline Na kakav se način zahtjev procjenjuje & $100 \%$ & $52,6 \%$ & $0,0 \%$ \\
\hline $\begin{array}{l}\text { Podatak o korištenju skala depresije i/ili } \\
\text { anksioznosti i /ili ljutnje }\end{array}$ & $100 \%$ & $8,8 \%$ & $0,0 \%$ \\
\hline Podatak o ispitivanju ometajućih ponašanja & $100 \%$ & $3,5 \%$ & $0,0 \%$ \\
\hline Podatak o primjeni upitnika/profila ličnosti & $100 \%$ & $8,8 \%$ & $0,0 \%$ \\
\hline Podatak o korištenju skala autodestruktivnosti & $100 \%$ & $1,8 \%$ & $0,0 \%$ \\
\hline Podatak o indeksu profila emocija & $100 \%$ & $10,5 \%$ & $0,0 \%$ \\
\hline $\begin{array}{l}\text { Podatak o korištenju skala strahova i anksioznosti } \\
\text { za djecu i adolescente }\end{array}$ & $100 \%$ & $7,0 \%$ & $0,0 \%$ \\
\hline $\begin{array}{l}\text { Podatak o korištenju testa nedovršenih rečenica } \\
\text { psihologa }\end{array}$ & $0,0 \%$ & $1,8 \%$ & $0,0 \%$ \\
\hline Podatak o korištenju projektivnih tehnika & $100 \%$ & $5,3 \%$ & $0,0 \%$ \\
\hline $\begin{array}{l}\text { Podatak o korištenju nekih drugih, gore } \\
\text { nenavedenih instrumenata }\end{array}$ & $100 \%$ & $7,0 \%$ & $0,0 \%$ \\
\hline Podatak o datumu procjene & $100 \%$ & $31,6 \%$ & $0,0 \%$ \\
\hline Podatak o vremenu procjene & $0,0 \%$ & $7,0 \%$ & $0,0 \%$ \\
\hline Ukupno & $81,0 \%$ & $13,6 \%$ & $0,0 \%$ \\
\hline
\end{tabular}

Rezultat prema kojem je u ostalim izvješćima prosječno prisutno tek $13,6 \%$ navoda o mjestu i načinu prikupljanja informacija te načinu donošenja procjene jasno govori da za veliku većinu maloljetnika nije poznat izvor informacija te jesu li primjenjivani neki instrumenti (i koji) za procjenu. 


\subsubsection{Tijek školovanja - potkategorija kategorije 10.}

Potkategorija kategorije 10. koja se odnosi na tijek školovanja dijelom opisuje osobine maloljetnika (iz kategorije 2.), dijelom njegove osobne prilike (iz kategorije 7.), ali ponajprije opisuje odgojno-obrazovni aspekt njegova života. Taj, inače koherentni sklop obilježja, koji zakonom nije posebno naveden, različito je uzet $\mathrm{u}$ obzir u analiziranim izvješćima. Najbolje popunjeno izvješće (tablica 9.) uzelo je u obzir oko $82 \%$ predviđenih obilježja, uz znakovit nedostatak onih koja se odnose na uspjehe i pozitivne aktivnosti. Najlošije popunjeno izvješće pruža samo četiri podatka pri čemu, uz objektivni obrazovni status, navodi samo problematične sadržaje (ponavljanje razreda, mijenjanje škole i prekid školovanja).

Tablica 9. Tijek školovanja

\begin{tabular}{|l|l|l|l|}
\hline $\begin{array}{l}\text { Tijek školovanja } \\
\text { Broj varijabli: } 22\end{array}$ & $\begin{array}{l}\text { Najbolje } \\
\text { popunjeno } \\
\text { izviješće }\end{array}$ & $\begin{array}{l}\text { Prosjek } \\
\text { popunjenosti } \\
\text { ostalih izvješća }\end{array}$ & $\begin{array}{l}\text { Najlošije } \\
\text { popunjeno } \\
\text { izvješće }\end{array}$ \\
\hline $\begin{array}{l}\text { Podatak o nagradama / sankcijama tijekom } \\
\text { školovanja }\end{array}$ & $100,0 \%$ & $7,0 \%$ & $0,0 \%$ \\
\hline Podatak o uključenosti u predškolsku ustanovu & $100,0 \%$ & $43,9 \%$ & $0,0 \%$ \\
\hline Podatak koju srednju školu pohađa ili je završio & $100,0 \%$ & $94,7 \%$ & $100,0 \%$ \\
\hline Podatak je li ponavljao razred & $100,0 \%$ & $75,4 \%$ & $100,0 \%$ \\
\hline Podatak izostaje li ili ne izostaje s nastave & $100,0 \%$ & $49,1 \%$ & $0,0 \%$ \\
\hline Podatak je li bježao s nastave & $100,0 \%$ & $24,6 \%$ & $0,0 \%$ \\
\hline Podatak o dobi polaska u osnovnu školu & $100,0 \%$ & $56,1 \%$ & $0,0 \%$ \\
\hline $\begin{array}{l}\text { Podatak koji razred osnovne/srednje škole je } \\
\text { prethodno završio }\end{array}$ & $100,0 \%$ & $78,9 \%$ & $0,0 \%$ \\
\hline Podatak je li je prekidao školovanje & $100,0 \%$ & $73,7 \%$ & $100,0 \%$ \\
\hline Podatak je li napuštao školovanje & $100,0 \%$ & $47,4 \%$ & $0,0 \%$ \\
\hline $\begin{array}{l}\text { Podatak o uspjehu koji je postigao u posljednjem } \\
\text { završenom razredu }\end{array}$ & $100,0 \%$ & $22,8 \%$ & $0,0 \%$ \\
\hline $\begin{array}{l}\text { Podatak je li imao izrazite teškoće u nekim } \\
\text { nastavnim predmetima }\end{array}$ & $100,0 \%$ & $15,8 \%$ & $0,0 \%$ \\
\hline $\begin{array}{l}\text { Podatak je li prisutan deficit znanja obrazovnog } \\
\text { sadržaja }\end{array}$ & $100,0 \%$ & $17,5 \%$ & $0,0 \%$ \\
\hline $\begin{array}{l}\text { Podatak o izrazitom uspjehu iz nekoga } \\
\text { obrazovnog područja }\end{array}$ & $0,0 \%$ & $1,8 \%$ & $0,0 \%$ \\
\hline Podatak o uključenosti u izvannastavne aktivnosti & $0,0 \%$ & $5,3 \%$ & $0,0 \%$ \\
\hline Podatak o uključenosti u izvanškolske aktivnosti & $0,0 \%$ & $10,5 \%$ & $0,0 \%$ \\
\hline Podatak je li mijenjao školu & $100,0 \%$ & $71,9 \%$ & $100,0 \%$ \\
\hline $\begin{array}{l}\text { Podatak jesu li utvrđene razlike u kronološkoj i } \\
\text { obrazovnoj dobi }\end{array}$ & $100,0 \%$ & $29,8 \%$ & $0,0 \%$ \\
\hline $\begin{array}{l}\text { Podatak o uključenosti u dopunsku / dodatnu } \\
\text { nastavu }\end{array}$ & $0,0 \%$ & $0,0 \%$ & $0,0 \%$ \\
\hline
\end{tabular}




\begin{tabular}{|l|l|l|l|}
\hline Podatak o prihvaćanju učenja i školskih obveza & $100,0 \%$ & $38,6 \%$ & $0,0 \%$ \\
\hline Podatak o odnosu prema profesorima & $100,0 \%$ & $19,3 \%$ & $0,0 \%$ \\
\hline Podatak o prihvaćenost u razredu & $100,0 \%$ & $17,5 \%$ & $0,0 \%$ \\
\hline Ukupno & $81,8 \%$ & $36,4 \%$ & $18,2 \%$ \\
\hline
\end{tabular}

Ostala izvješća u prosjeku pružaju tek malo više od trećine predviđenih podataka o tijeku školovanja i pritom pretežu oni koji opisuju problematične sadržaje.

\subsubsection{Način provođenja slobodnog vremena - potkategorija kategorije 10.}

Strukturiranje slobodnog vremena, u kombinaciji s drugim informacijama važno je i za odluku o odgojnoj mjeri i za tretmanske postupke. Najbolje ispunjeno izvješće pružilo je dobar dio informacija, a najlošije nije obuhvaćalo niti jednu od traženih informacija.

Tablica 10. Način provođenja slobodnoga vremena

\begin{tabular}{|l|l|l|l|}
\hline Način provođenja slobodnoga vremena & $\begin{array}{l}\text { Najbolje } \\
\text { popunjeno } \\
\text { izvješće }\end{array}$ & $\begin{array}{l}\text { Prosjek } \\
\text { popunjenosti } \\
\text { ostalih izvješća }\end{array}$ & $\begin{array}{l}\text { Najlošije } \\
\text { popunjeno } \\
\text { izvješće }\end{array}$ \\
\hline $\begin{array}{l}\text { Podatak o načinu provođenja slobodnog } \\
\text { vremena općenito }\end{array}$ & $100,0 \%$ & $57,9 \%$ & $0,0 \%$ \\
\hline Podatak o svrsi korištenja slobodnog vremena & $100,0 \%$ & $12,3 \%$ & $0,0 \%$ \\
\hline Podatak s kim se druži u slobodno vrijeme & $100,0 \%$ & $38,6 \%$ & $0,0 \%$ \\
\hline $\begin{array}{l}\text { Podatak o načinu provedbe slobodnog vremena } \\
\text { osoba s kojima se druži }\end{array}$ & $0,0 \%$ & $12,3 \%$ & $0,0 \%$ \\
\hline Ukupno & $75,0 \%$ & $30,3 \%$ & $0,0 \%$ \\
\hline
\end{tabular}

Ostala su izvješća prosječno vrlo štura. Najčešće je spomenut općeniti podatak o načinu provođenja slobodnog vremena, no činjenica da se, primjerice, maloljetnik druži s vršnjacima ne govori mnogo.

\subsubsection{Ranije intervencije - potkategorija kategorije 10.}

Centar za socijalnu skrb ima pohranjene podatke o ranijim intervencijama prema maloljetniku i/ili njegovoj obitelji. Priroda je tih intervencija važna za dobivanje cjelokupne slike o maloljetniku. Dok su u najbolje ispunjenom izvješću one navedene uz opis njihove učinkovitosti, u najlošijem nisu niti spomenute.

Tablica 10. Ranije intervencije

\begin{tabular}{|l|l|l|l|}
\hline $\begin{array}{l}\text { Ranije intervencije } \\
\text { Broj varijabli: 2 }\end{array}$ & $\begin{array}{l}\text { Najbolje } \\
\text { popunjeno } \\
\text { izvješće }\end{array}$ & $\begin{array}{l}\text { Prosjek } \\
\text { popunjenosti } \\
\text { ostalih izvješća }\end{array}$ & $\begin{array}{l}\text { Najlošije } \\
\text { popunjeno } \\
\text { izvješće }\end{array}$ \\
\hline $\begin{array}{l}\text { Podatak o ranijim intervencijama prema } \\
\text { maloljetniku }\end{array}$ & $100,0 \%$ & $77.19 \%$ & $0,0 \%$ \\
\hline
\end{tabular}




\begin{tabular}{|l|l|l|l|}
\hline $\begin{array}{l}\text { Podatak o učinkovitost dosadašnjih intervencija } \\
\text { prema maloljetniku }\end{array}$ & $100,0 \%$ & $49.12 \%$ & $0,0 \%$ \\
\hline Ukupno & $100 \%$ & $63,2 \%$ & $0,0 \%$ \\
\hline
\end{tabular}

U gotovo $80 \%$ ostalih izvješća ranije su intervencije spomenute, no samo u $50 \%$ slučajeva spomenuto je i kakav je bio njihov rezultat. U slučaju neuspjeha intervencije, sud bi znao za dodatni neriješeni problem i to bi uzeo u obzir.

\subsubsection{Prijedlog odgojne mjere i preporuke za tretman - potkategorija kategorije 10.}

Zakonom nije izrijekom navedeno da bi sud trebao pribaviti prijedlog odgojne mjere, iako kategorija 10 . i to očevidno podrazumijeva. Naime, procjena rizika i tretmanskih potreba te prijedlog sankcije za maloljetne počinitelje zadatak je stručnih suradnika izvan pravne struke u državnim odvjetništvima i na sudu. ${ }^{30} \mathrm{Za}$ to su im potrebna kvalitetna izvješća centara za socijalnu skrb. Međutim, kako je vidljivo iz tablice 11., gotovo sve potrebne podatke pružalo je najbolje ispunjena izvješće, a niti jedan podatak u tom smislu nije dalo najlošije izvješće.

Tablica 11. Prijedlog odgojne mjere i preporuke za tretman

\begin{tabular}{|l|l|l|l|}
\hline $\begin{array}{l}\text { Prijedlog odgojne mjere i preporuke za tretman } \\
\text { Broj varijabli: } 13\end{array}$ & $\begin{array}{l}\text { Najbolje } \\
\text { popunjeno } \\
\text { izvješće }\end{array}$ & $\begin{array}{l}\text { Prosjek } \\
\text { popunjenosti } \\
\text { ostalih izvješća }\end{array}$ & $\begin{array}{l}\text { Najlošije } \\
\text { popunjeno } \\
\text { izvješće }\end{array}$ \\
\hline Pozitivna uporišta & $100 \%$ & $5,3 \%$ & $0,0 \%$ \\
\hline Rizični čimbenici & $100 \%$ & $15,8 \%$ & $0,0 \%$ \\
\hline Zaštitni čimbenici & $100 \%$ & $5,3 \%$ & $0,0 \%$ \\
\hline $\begin{array}{l}\text { Preporuke za daljnje tretmansko postupanje na } \\
\text { obrazovnom području }\end{array}$ & $100 \%$ & $3,5 \%$ & $0,0 \%$ \\
\hline $\begin{array}{l}\text { Preporuke za tretmansko djelovanje na odgojnom } \\
\text { području }\end{array}$ & $100 \%$ & $15,8 \%$ & $0,0 \%$ \\
\hline $\begin{array}{l}\text { Podatak koji odgovara na pitanje na koja odgojna } \\
\text { sredstva reagira }\end{array}$ & $100 \%$ & $3,5 \%$ & $0,0 \%$ \\
\hline Podatci koji argumentiraju prijedlog & $100 \%$ & $19,3 \%$ & $0,0 \%$ \\
\hline Preporuka što je potrebno u daljnjem radu s istim & $100 \%$ & $19,3 \%$ & $0,0 \%$ \\
\hline Prijedlog odgojne mjere & $100 \%$ & $24,6 \%$ & $0,0 \%$ \\
\hline Podatak koje je uvjete ispitaniku potrebno osigurati & $100 \%$ & $7,0 \%$ & $0,0 \%$ \\
\hline $\begin{array}{l}\text { Podatak o predikciji daljnjega razvoja poremećaja } \\
\text { u ponašanju }\end{array}$ & $100 \%$ & $8,8 \%$ & $0,0 \%$ \\
\hline $\begin{array}{l}\text { Podatak o procjena rizičnosti za daljnje činjenje } \\
\text { kaznenih djela }\end{array}$ & $0,0 \%$ & $5,3 \%$ & $0,0 \%$ \\
\hline Podatak o svrsi predložene mjere & $100 \%$ & $14,0 \%$ & $0,0 \%$ \\
\hline Ukupno & $93,3 \%$ & $15,2 \%$ & $0,0 \%$ \\
\hline
\end{tabular}

30 Čl. 43. st. 2. Zakona o sudovima za mladež. 
Kod četvrtine ostalih izvješća postojao je prijedlog odgojne mjere, a ostali podatci u smislu rizika, potreba i preporuka za tretman prisutni su u rasponu od 3,5 $\%$ do $19,3 \%$. Bez vodiča ili barem preporuke o načinu pisanja izvješća, manji dio centara za socijalnu skrb percipirao je da ti podatci trebaju ući u izvješće, a veći dio nije tome pridavao pažnju. Provedenom analizom podataka, što je bio prvi cilj rada, može se zaključiti da svaki maloljetni počinitelj nije tretiran jednako, počevši od različitih i uglavnom nepoznatih načina prikupljanja podataka do njihove količine $\mathrm{i}$ vrste u svakoj od 10 zakonskih kategorija. To govori u prilog potrebi standardizacije izvješća centara za socijalnu skrb s posebnim osvrtom na moguće narušavanje načela nemo tenetur se ipsum accusare. Time je ispunjen drugi cilj rada.

\section{PRIJEDLOZI IZMJENA I DOPUNA ZAKONSKIH I IZRADA PODZAKONSKIH PROPISA}

Treći je cilj rada ponuditi izmjene i dopune zakonskih te predložiti izradu podzakonskih propisa.

\subsection{Prijedlog izmjene čl. 78. ZSM/11}

1. U postupku prema maloljetniku, uz činjenice koje se odnose na kazneno djelo, pribavit će se podatci potrebni za ocjenu njegove psihofizičke razvijenosti i podatci o osobnim i obiteljskim prilikama po propisanom obrascu s točno određenim obvezatnim podatcima.

2. Radi utvrđivanja tih okolnosti obvezatno će se ispitati maloljetnikov roditelj, njegov skrbnik i druge osobe koje mogu dati potrebne podatke. Te podatke prikuplja nadležni centar za socijalnu skrb, a ako je prema maloljetniku bila primijenjena odgojna mjera, centar dostavlja i izvješće o njezinoj primjeni.

3. Za maloljetnika za kojeg nije u prethodnom postupku odlučeno po odredbama članka 70., 71., 72. i 73. ZSM/11, prije podnošenja prijedloga za izricanje odgojne mjere nadležnom sudu, provest će se timska procjena u specijaliziranim ustanovama socijalne skrbi (ambulantna ili stacionarna).

4. Timska je procjena interdisciplinarni postupak prikupljanja podataka o maloljetniku, koji u ustanovama socijalne skrbi provodi tim stručnjaka različitih profila, primarno socijalni radnik, socijalni pedagog i psiholog, uz uključivanje stručnjaka drugih specijalnosti (psihijatar, liječnik školske medicine i drugi), radi utvrđivanja obiteljskih prilika, odgojnog potencijala i kompetencija obitelji, dinamike odnosa u obitelji, psihičkog statusa maloljetnika (struktura sposobnosti i ličnosti) te etiologije, fenomenologije oblika i intenziteta poremećaja u ponašanju i ličnosti uz utvrđivanje rizičnih i zaštitnih čimbenika te kriminogenih rizika. Provođenje dijagnostike osnova je za predlaganje odgovarajućih odgojnih mjera, zaštite i tretmana maloljetnika. Pojedinačna mišljenja članova stručnog tima sintetiziraju se u Obradu i mišljenje Stručnog tima, a po završetku cjelovito provedene dijagnostičke obrade, sintetiziraju se u Nalaz i mišljenje.

5. O obveznim podatcima i načinu prikupljanja podataka o maloljetniku kao i 
o postupcima timske procjene Ministarstvo pravosuđa i uprave te Ministarstvo rada, mirovinskog sustava, obitelji i socijalne politike donijet će Pravilnik o prikupljanju podataka, načinu prikupljanja podataka i standardiziranom izvješću Centra za socijalnu skrb kao i timskoj procjeni maloljetnika te davanju stručnog mišljenja o izboru vrste maloljetničke sankcije.

\subsection{Prijedlog izmjene čl. 83.a ZSM/11}

Sud će na temelju izvješća stručnoga suradnika, centra za socijalnu skrb ili drugih stručnih osoba ili tijela utvrditi jesu li tijekom trajanja postupka nastupile bitne promjene u odnosu na podatke iz čl. 78. Zakona. Ako su te promjene nastupile i/ili je proteklo više od godine dana od ranije procjene, sud će naložiti provođenje dodatne timske procjene maloljetnika.

\subsection{Prijedlog izmjene čl. 84. ZSM/11}

(1) Na sjednicu vijeća pozvat će se državni odvjetnik, maloljetnik, branitelj, roditelji maloljetnik, odnosno skrbnik, žrtva i oštećenik i predstavnik specijalizirane ustanove socijalne skrbi koja je provela timsku procjenu.

Zaključno slijedi da centri za socijalnu skrb ostaju glavni generator podataka na početku postupka, a pisanje izvješća ostaje temelj i prva radnja u kaznenom postupku prema maloljetniku. No, pritom je nužno ujednačiti način i vrstu potrebnih podataka kako bi svaki maloljetnik bio tretiran jednako. Tako prikupljeni podatci, međutim, samo čine podlogu za kvalitetnu multidisciplinarnu obradu svakoga maloljetnika koji ulazi u kazneni sustav. Stoga bi, prije podnošenja optužnog akta, druga obvezatna radnja u istom kaznenom postupku bila timska procjena ranijeg naziva dijagnostika. Za nju u Hrvatskoj već postoje organizacijske pretpostavke i specijalizirani stručnjaci. Riječ je, naime o odjelima stacionarne timske procjene kojih za sada u Hrvatskoj ima sedam, a način njihova rada, njihove prednosti i buduća uloga $u$ istom kontekstu detaljnije su opisani ranije. ${ }^{31}$

Za napomenuti je da bi se u tom smislu promijenile uloge predstavnika centra za socijalnu skrb, odnosno stručnoga suradnika državnog odvjetništva i stručnog suradnika suda iz čl. 5. toč. 8., odnosno čl. 7. toč. 1. Pravilnika. ${ }^{32}$ Naime, njihovo mišljenje i prijedlog izricanja primjerene maloljetničke sankcije zamijenio bi postupak timske procjene i Obrada i mišljenje Stručnog tima" te bi predstavnik tog tima iznio mišljenje na sjednici vijeća ili raspravi u kaznenom postupku.

Stručni suradnici bi u tom stadiju postupka imali savjetodavnu ulogu i stručnu potporu državnom odvjetniku, odnosno sucu za mladež radi razjašnjavanja nalaza i mišljenja timske procjene provedene u specijaliziranoj ustanovi socijalne skrbi. Ostala nadležnost i poslovi stručnoga suradnika državnog odvjetništva, odnosno

31 Više u: Vučić Blažić, Prema standardizaciji kriterija za izricanje odgojnih mjera počiniteljima kaznenih djela na primjeru upućivanja u disciplinski centar.

32 Pravilnik o radu stručnih suradnika izvanpravne struke na poslovima delinkvencije mladih i kaznenopravne zaštite djece u državnim odvjetništvima i na sudovima, Narodne novine, br. 22/13.-369. 
suda u prethodnom / pripremnom postupku i u postupku provođenja odgojnih mjera i drugih maloljetničkih sankcija bi ostali.

Kako su mlađi punoljetnici osobe vrlo mlade životne dobi autorice su mišljenje da im treba posvetiti posebnu pozornost. U tom pogledu, ovakve izmjene maloljetničkoga zakonodavstva odnosile bi se i na kazneni postupak prema mlađim punoljetnicima u smislu čl. 107. st. 1. i 2. ZSM/11 u vezi čl. 78. ZSM/11. Naime, propisi koji uređuju nadležnost specijaliziranih ustanova socijalne skrbi koji provode dijagnostiku / opservaciju, uređuju nadležnost ne samo za maloljetnike koji se pojave kao počinitelji kaznenog djela, već i za mlađe punoljetnike.

\section{ZAKLJUČAK}

Svrha je ovog rada, na temelju rezultata provedenog istraživanja, procijeniti primjenu jednakosti u postupovnom pristupu prema svakom maloljetniku radi osiguravanja pravičnog suđenja i jednakosti svih pred zakonom i s tim u vezi ponuditi konkretne izmjene zakonskih i donošenje podzakonskih propisa.

Prvi se cilj rada odnosio na utvrđivanje vrste i količine podataka koje izvješća centara za socijalnu skrb sadrže s obzirom na svaku od 10 kategorija podataka koje sud uzima u obzir pri donošenju odluke o odgojnoj mjeri. Iz dobivenih rezultata vidljivo je da centrima za socijalnu skrb nije do kraja jasno koje vrste podataka skupljati i kako. Prosječna je popunjenost izvješća između $12 \%$ i $63 \%$ očekivanih podataka odabranih diskrecijskom odlukom izvjestitelja.

Drugi se cilj rada odnosi na procjenu primjene jednakoga postupovnog pristupa prema svakom maloljetniku radi osiguravanja pravičnog suđenja i jednakosti svih pred zakonom u fazi procjene. Iz rezultata je jasno da svaki maloljetni počinitelj nije tretiran jednako. U pravilu je način prikupljanja podataka nepoznat, a količina $\mathrm{i}$ vrsta podataka u svakoj od 10 zakonskih kategorija znatno se razlikuje u izvješćima. To onemogućuje primjenu jednakoga postupovnog pristupa i stručnim suradnicima u državnom odvjetništvu i na sudu jer se njihove procjene temelje na podatcima iz navedenih izvješća.

Treći je cilj rada bio ponuditi konkretne izmjene i dopune zakonskih te izradu podzakonskih propisa, a prijedlozi su navedeni u 5. poglavlju ovoga rada.

\section{LITERATURA}

1. Ajduković, Marina. „Psihologijski aspekti donošenja odluka u kaznenom postupku“. Hrvatski ljetopis za kazneno pravo i praksu 2, (1995): 292-307.

2. Alexander, Jr., Rudolf Counseling. Treatment and Intervention - Methods with Juvenile and Adult Offenders. Belmont: Brooks/Cole-Thomson learning, 2000.

3. Berryessa, Colleen M. i Jillian Reeves. „The Perceptions of Juvenile Judges Regarding Adolescent Development in Evaluating Juvenile Competency“. Journal of Criminal Law and Criminology 110, br. 3 (2020): 551-592.

4. Bojanić, Igor i Đurđević Zlata. „Dopuštenost uporabe dokaza pribavljenih kršenjem temeljnih ljudskih prava“. Hrvatski ljetopis za kazneno pravo i praksu. 15, br. 2 (2008): 973-1003. 
5. Božićević Grbić, Melita i Mirta Kuharić. Zakon o sudovima za mladež - primjena u praksi, Priručnik za polaznike/ice. Zagreb: Pravosudna akademija, 2017.

6. Carić, Ante i Ivan Kustura. „Kamo ide hrvatsko maloljetničko kazneno zakonodavstvo?“. Zbornik radova Pravnog fakulteta u Splitu 47, br. 3 (2010): 605-620.

7. Dunkel, Frieder. „Juvenile Justice Systems in Europe - reform developments between justice, welfare and new punitivness“". Kriminologijos studios br. 1 (2014): 31-76. DOI: 10.15388/ CrimLithuan.2014.0.3676

8. Europska konvencija za zaštitu ljudskih prava i temeljnih sloboda, Narodne novine - MU, br. 18/97., 6/99., 14/0.2, 13/03., 9/05., 1/06, 2/10.

9. Hannah-Moffat, Kelly. „Criminogenic needs and the transformative risk subject: Hybridizations of risk/need in penalty“. Punishment \& Society 7, br. 1 (2005): 29-51.

10. Kazneni zakon, Narodne novine, br. 125/11., 144/12., 56/15., 61/15., 101/17., 118/18., $126 / 19$.

11. Koller-Trbović, Nivex, Anja Mirosavljević i Ivana Jeđud Borić. Procjena potreba djece i mladih s problemima u ponašanju- konceptualne i metodičke odrednice. Zagreb: Ured UNICEF-a za Hrvatsku, 2017.

12. Konvencija o pravima djeteta, (1989). Convention on the Rights of the Child Adopted and opened for signature, ratification and accession by General Assembly resolution 44/25 of November 1989, entry into force 2 September 1990, in accordance with article 49. Pristup: 20. ožujka 2018. https://www.ohchr.org/en/professionalinterest/pages/crc.aspx

13. Koren Mrazović, Marija. „Maloljetnici i mlađi punoljetnici s poremećajima u ponašanju u tretmanu socijalne skrbi u Republici Hrvatskoj“. Kriminologija \& socijalna integracija: časopis za kriminologiju, penologiju i poremećaje u ponašanju 6, № 2 (1998): 141-152.

14. Križ, Đurđa. „Kriteriji za odabir odgojnih mjera maloljetnicima u svjetlu primjene Zakona o sudovima za mladež“. Hrvatski ljetopis za kazneno pravo i praksu 6, br. 2 (1999): 366368.

15. Lulić Čavar, Gordana. „Neki aspekti evaluacije učinkovitosti tijeka izvršenja odgojne mjere upućivanja u disciplinski centar za maloljetnike“. Kriminologija i socijalna integracija 3, br. 1 (1995): 53-70.

16. Mears, Daniel. „Sentencing Guidelines and the Transformation of Juvenile Justice in the $21^{\text {st }}$ Century“. Journal of Contemporary Justice 18, br. 1 (2002): 6-19.

17. Međunarodni pakt o građanskim i političkim pravima: MPGPP, (1966). Pristup 11. kolovoza 2019. https://pravosudje.gov.hr/UserDocsImages/dokumenti/Pravo\%20na\%20 pristup\%20informacijama/Zakoni\%20i\%20ostali\%20propisi/UN\%20konvencije/ Medjunarodni pakt_o gradjanskim i politickim pravima_HR.pdf.

18. Mikšaj-Todorović, Ljiljana i Maja Vučić Blažić. „Kriteriji za izricanje odgojnih mjera“. Zbornik Pravnog fakulteta Sveučilišta u Rijeci 41, br. 2 (2020): 445-465.

19. New Jersey Code, Purposes, 2009. Pristup 16. siječnja 2020. https://law.justia.com/ codes/new-jersey/2009/title-2a/2a-4a-21.

20. Petö Kujundžić, Lana. „Prava djece u kaznenom maloljetničkom pravu prema međunarodnim i europskim standardima“. U: Novine u kaznenom zakonodavstvu, Zbornik radova, Opatija; (2017): 13-24 (bez navođenja urednika). Opatija: Vrhovni sud RH i RH Pravosudna akademija, 2017.

21. Petrak, Marko. „Kanonsko pravo i hrvatski pravni sustav (I). Pravni izvori i pravna načela“. Zbornik Pravnog fakulteta u Zagrebu 70, br. 2/3 (2020): 251-286.

22. Pravilnik o radu stručnih suradnika izvanpravne struke na poslovima delinkvencije mladih i kaznenopravne zaštite djece u državnim odvjetništvima i na sudovima, Narodne novine, br. 22/13.

23. Radić, Ivana. „Hrvatski sustav maloljetničkih sankcija: trenutačno stanje i prijedlozi za promjenu“. Hrvatski ljetopis za kaznene znanosti i praksu 24, br. 1 (2017): 3-115. 
24. Ricijaš, Neven. „Dobre prakse i izazovi u kontekstu maloljetničke delinkvencije u Hrvatskoj“. U: ur. Ranko Kovačević i sur. Maloljetnička delinkvencija - dijalog, razmjena iskustava i znanja, 1-33. Tuzla: OFF SET, 2017.

25. Ricijaš, Neven. „Instrumenti procjene djece i adolescenata-mogućnosti primjene kod probacije za maloljetnike“. Ljetopis socijalnog rada 13, br. 2 (2006): 271-295.

26. Rittossa, Dalida i Melita Božićević Grbić. „Zakon o sudovima za mladež - reformski zahvati i praktične dileme“. Hrvatski ljetopis za kazneno pravo i praksu 19, br. 2 (2012): 615-667.

27. Robinson, Gwen. „Risk and risk assessment“. U Moving Probation Forward, eds. Wing Hong Chui, Mike Nellis, 108-128. London: Pearson PLC, 2003.

28. Singer, Mladen, Konstantin Momirović i Vojislav Kovačević. „Kriteriji sudova pri izricanju sankcija maloljetnicima“. Defektologija 12, br. 1-2 (1976): 48-121.

29. Smjernice Odbora ministara Vijeća Europe o pravosuđu prilagođenom djeci, Odbor ministara VE, 2010, Program VE "Izgradnja Europe za djecu i s djecom". Izdavaštvo VE. Pristup: 22. veljače 2020. https://rm.coe.int/CoERMPublicCommonSearchServices/ DisplayDCTMContent?docume ntId=09000016806a450a

30. Takahashi, Masaru. „Assessment of Juvenile offenders at juvenile Classification Homes in Japan. UN Asia and Far east Institute for the Prevention of Crime and the Treatment of Offendesr (UNAFEI)“. Resource material 78, (2009): 151-158.

31. Ustav Republike Hrvatske, Narodne novine, br. 56/90., 135/97., 08/98., 113/00., 124/00., 28/01., 41/01., 55/01., 76/10., 85/10., 05/14.

32. Van Voorhis Patricia, Michael Braswell i David Lester. Correctional Counseling\&Rehabilitation. $4^{\text {th }}$ ed. Cincinnati: Anderson Publishing, 2000.

33. Vučić Blažić, Maja. Prema standardizaciji kriterija za izricanje odgojnih mjera počiniteljima kaznenih djela na primjeru upućivanja u disciplinski centar: Završni specijalistički rad. Rijeka: Sveučilište u Rijeci, 2020.

34. Walsh, Anthony. Correctional Assessment, casework \& Counseling. $4^{\text {th }}$ ed. Alexandria: American Correctional Association, 2020.

35. Williams, Frank P. III, Marilyn D. McShanew i Michael Dolny H. „Developing a parole classification instrument for use as a management tool“. Corrections Management Quarterly 4, br. 4 (2000): 45-59.

36. Zakon o sudovima za mladež, Narodne novine, br. 84/11., 143/12., 56/15. i 126/19.

37. Zermatten, Jean. The best Interests of the Child. Literal Analysis, Function and Implementation, Working Report. Bramois, Institut international des droits de l'enfant, 2009.

38. Zhuang Liu, John, Li Xueyao. „Legal Techniques for Rationalizing Biased Judicial Decisions: Evidence from Experiments with Real Judges“. Journal of Empirical Legal Studies 16, br. 3 (2019): 630-670. 


\author{
Maja Vučić Blažić* \\ Ljiljana Mikšaj - Todorovié** \\ Dijana Rizvić****
}

\title{
EQUAL PROCEDURAL TREATMENT TO EACH JUVENILE IN CRIMINAL PROCEDURE IN ORDER TO ENSURE A FAIR TRIAL AND EQUALITY OF ALL BEFORE LAW
}

\begin{abstract}
Summary
The purpose of this paper is, based on the results of the research, to assess the application of equal procedural treatment to each juvenile in order to ensure a fair trial and equality of all before the law and in this regard to offer concrete changes in laws and regulations. The content of reports of social welfare centers $(N=59)$ that are compiled for the needs of the court when imposing educational measures was analyzed. The results showed that the reports differed significantly and that, within each of the 10 legally defined categories, on average between $12 \%$ and $63 \%$ of the expected data selected by the discretion of the rapporteur were present. This argues the conclusion that the application of equality of procedural treatment to each juvenile in the assessment phase has been violated. The paper presents proposals for amendments to laws and drafting bylaws in order to improve the application of equality of procedural treatment.
\end{abstract}

Keywords: criminal offenses; criteria; correctional measures; reports; juvenile court.

\footnotetext{
* Maja Vučić Blažić, univ. spec. crim., Senior expert treatment advisor, Prison Hospital in Zagreb; vucicblazicmaja@gmail.com. ORCID: https://orcid.org/0000-0001-5289-4681.

** Ljiljana Mikšaj-Todorović, Ph.D., Full Professor, Faculty of Education and Rehabilitation Sciences University of Zagreb, Department of Criminology; 1jiljana.miksaj-todorovic@erf.hr. ORCID: https://orcid.org/0000-0003-2347-6696.

*** Dijana Rizvić, mag. iur., Judge, Municipal Criminal Court in Zagreb, Juvenile Department; dijanarizvić@gmail.com. ORCID: https://orcid.org/0000-0001-5659-2038.
} 